\title{
Soberania popular, cidadania, e nação na América Hispânica: a experiência republicana do século XIX
}

Popular Sovereignty, Citizenship, and Nation-Building in Nineteenth Century Spanish America: The Republican Experiment

\section{Hilda Sabato}

Professora na Faculdade de Filosofia e Letras da Universidade de Buenos Aires (UBA) e pesquisadora do Conselho Nacional de Investigações Científicas e Tecnológicas (CONICET - Argentina) e-mail: hsabato@arnet.com.ar
Este ensaio recolhe, articula e amplia idéias e argumentos parcialmente desenvolvidos em vários de meus trabalhos anteriores, citados na bibliografia final. Apresentei versões preliminares deste texto em seminários da Universidade de Paris I e na Universidade de Emory.

\section{Resumo}

Este ensaio analisa a mudança política de longo prazo que teve início com a revolução de independência na América Hispânica: a experiência republicana do século XIX. A adoção do princípio de soberania popular para fundar e legitimar o governo e a autoridade, comum para quase todas as tentativas de conformação de novas comunidades políticas após a ruptura da ordem monárquica espanhola, trouxe mudanças decisivas nas normas, nas instituições e nas práticas politicas. Para analisar tais mudanças, este ensaio recorre à categoria de "cidadania" como lente de observação que permite o questionamento sobre a participação política e as formas de inclusão/ exclusão na república. Na base de uma ampla bibliografia disponível sobre o assunto, são explorados traços e tendências compartilhados em relação com a instituição da cidadania em três de suas fases mais estudadas até hoje: a eleitoral, a das armas e a que se refere à opinião pública.

\begin{abstract}
The purpose of this paper is to reflect upon the vast and long-term political change triggered by the fall of the Spanish Empire and the wars of independence in Spanish America. After the revolutions, attempts at nation building followed different directions, but all the new polities in the making adopted republican forms of government based on the principle of popular sovereignty. This "republican experiment" entailed a radical change in political norms and institutions, as well as in political practices. By resorting to the category of "citizenship", this essay focuses on one aspect of that vast political transformation, which pertains to political participation and to the borders of inclusion and exclusion from the polity. On the basis of the recent literature on these topics, it explores the institution of citizenship in nineteenth-century Spanish America.
\end{abstract}

\section{Palavras-chave}

cidadania, república / republicanismo, práticas políticas, nação, América espanhola, representações políticas

\section{Keywords}

citizenship, republic / republicanism, political practices, nation, Spanish America, political representations 
0 propósito deste ensaio é refletir sobre a mudança política de longo prazo inaugurada com a revolução de independência na América Hispânica: a experiência republicana do século XIX. Mais do que de "experiência" deveriamos falar de "experiências", porque do mesmo modo que o sintagma "revolução de independência" oculta tudo o que de diverso, incerto e plural teve esse processo, também o uso do singular resume de um modo certamente errado a história dos projetos, ensaios, sucessos e fracassos da construção de formas republicanas de governo ao longo do século XIX no vasto território americano. Portanto, é de meu interesse centrar o foco naquilo que foi um denominador comum em todas as revoluções e independências, excetuando parcialmente o Brasil: a opção, mais cedo ou mais tarde, pelas formas republicanas de governo. Esse resultado não estava inscrito nas origens e também não implicou em transitar pelos caminhos lineares da organização política. Porém, desde a Nova Espanha até o Rio da Prata , a adoção do princípio de soberania popular para fundar e legitimar o governo e a autoridade foi comum em quase todas as tentativas de conformação de novas comunidades políticas depois da ruptura da ordem monárquica espanhola - tanto das exitosas quanto das frustradas. Mesmo que aquele principio tenha sido propagado havia muito tempo no mundo ocidental em geral, e no hispânico em particular, sua aplicação através de fórmulas republicanas, ensaiadas em grande escala na América Hispânica foi, se não original, pelo menos bastante arriscada e aventureira.

As novas bases de criação e reprodução do poder trouxeram mudanças decisivas nas normas, instituições e práticas políticas em vigência na colônia, com destinos e resultados bastante diversos. Contudo, durante décadas nação foi sinônimo de república, mesmo que os significados de uma e de outra fossem múltiplos, e que tenham sido motivo de profundas e sangrentas disputas que permearam boa parte do século XIX. Como também é verdade que estes processos tenham afetado a todos e cada um dos habitantes das terras americanas, cujos lugares no mundo se viram estremecidos devido à ruptura da ordem colonial, à materialidade da guerra e aos sucessivos ensaios de criação de novos poderes políticos, baseados no princípio da soberania popular. Este é o ponto de partida daquilo que eu gostaria de discutir nas páginas que se seguem.

Não existe uma via única para abordar esta variada gama de problemas; optei por uma delas, a que pode ser resumida em torno da categoria de "cidadania", uma categoria que ocupa um lugar central nos debates políticos de hoje, mas que também no século XIX fez parte das preocupações, das linguagens e das práticas políticas dos contemporâneos, se bem que com valores diferentes dos atuais. Eu a uso como uma lente de observação para me perguntar, em suma, pela questão da participação política e

Neste ensaio optei pela não inclusão de citações bibliográficas nas notas de rodapé e por uma bibliografia final, a qual mostra as fontes desta reflexão de um modo mais apropriado do que qualquer outro tipo de referência mais específica. pelas formas de inclusão / exclusão na república. ${ }^{2}$

\section{(2)}

Contamos hoje com uma farta literatura que de um modo ou de outro, toca na questão da cidadania. A historiografia mais recente tem dedicado grande parte de seus esforços para analisar as tentativas de conformação de repúblicas, em diferentes versões e formatos, e tem aberto à indagação um leque de problemas vinculados com as dimensões simbólicas e práticas envolvidas na construção, conservação, reprodução e legitimação do poder dentro desse contexto. E mesmo que nem tudo o que tenha sido escrito 
seja inovador ou original, a produção destes anos todos tem resultado num conjunto de imagens e interpretações do século XIX bastante diferentes das que existiam há vinte anos.

É lugar comum falarmos da renovação historiográfica que tem percorrido a história política. Não vou voltar sobre esta questão, a não ser para ressaltar uma de suas peculiaridades em relação com a nossa história regional: a existência de uma dimensão hispano-americana - e ainda iberoamericana - em todo este processo de renovação, o que sem dúvida constitui uma novidade. Porque se as ciências sociais dos anos 60 tematizaram a "América Latina", na nossa disciplina predominaram as histórias nacionais, com escassa referência para os processos de escala regional, ou continental. E ainda mais: a produção acadêmica de um país circulava muito pouco entre os outros paises e era encontrada nas bibliotecas dos Estados Unidos e da Europa.

Nesse sentido, a história política mais recente mostra uma notável mudança. A partir do interesse pelas questões nacionais, foi sendo gerado um espaço maior de interlocução e debate em escala regional e interregional. Para muitos de nós ficou claro que vários problemas que iam sendo descobertos nos nossos respectivos paises, faziam parte de fenômenos mais extensos e que só ganhavam sentido quando pensados dentro dessa interação. Em conseqüência disso, foi sendo gerada uma tendência de incluir um olhar comparativo, de estabelecer um diálogo intenso em nivel regional, mas sobretudo, de pensar os temas nacionais como fazendo parte de um conjunto mais abrangente, em que a Espanha e o mundo atlântico também ocupam um lugar chave.

Gostaria de colocar minhas reflexões dentro deste contexto, porque considero que abordar a complexidade das experiências republicanas numa tentativa de sintese que acabe não simplificando a história é uma tarefa superior às minhas forças; entretanto considero atraente e possivel o exercício de abranger em conjunto a produção historiográfica latino-americana que cuida daquelas experiências, para poder questioná-la no recorte de uma perspectiva em particular: aquela que focaliza a cidadania.

\section{(3)}

Voltarei então, para o ponto de partida: a opção republicana. Num momento em que a própria Europa reforçava sua aposta pela monarquia, inclusive a absolutista, as Américas, com a única exceção do Brasil, voltaram-se para as formas republicanas de governo, transformando-se num formidável campo de experimentação política. Uma vez caída a monarquia e desmontado o império espanhol - o que incluía seus domínios americanos - a reconstrução da ordem política foi sendo tentada sob o principio da soberania popular, junto com a necessidade de dar forma às comunidades - "nações" - novas que, além disso, deviam ser fonte de poder soberano e espaço de exercício desse poder. Nenhum desses processos teve um sucesso imediato ou fez um caminho linear.

Nas primeiras décadas pós-revoluções, a discussão em torno das formas de soberania teve um percurso conflitante. A noção liberal de nação como entidade abstrata de soberania única e indivisivel e integrada por indivíduos livres e iguais - os cidadãos - circulou desde cedo em concorrência com outras e, quando conseguiu sua imposição, ela não foi feita sem ambigüidades ou matizes. Junto com ela foi afirmado também o critério moderno de representação: como muito bem apontou François Guerra, 
ROSANVALLON, Pierre. Le sacré du citoyen. Paris: Gallimard, 1992. p.14. soberania popular, representação e nação foram conceitos concatenados que denominaram, também, realidades estreitamente vinculadas. Por isso os ensaios para criar nações - tanto os exitosos quanto os falidos, que foram maioria - chegaram da mão daqueles que tinham experiência em matéria de ordem política. Pensar a nação era, ao mesmo tempo, desenhar, iniciar e sustentar as instituições políticas. Os debates e as lutas em torno do centralismo / confederacionismo / federalismo; da divisão ou não dos poderes; da legitimidade dos poderes extraordinários e até da ditadura; do presidencialismo e parlamentarismo; e também, dos alcances e limites da cidadania, estavam no centro da problemática de nação. Ao longo do século XIX foram ensaiadas variantes muito diferentes, mas quase todas elas, gostaria de sublinhar, dentro de contextos que eram considerados republicanos.

A definição da cidadania foi um aspecto indissociável desta história. Sua introdução sugeria, como tem colocado Pierre Rosanvallon, "uma ruptura completa com as visões tradicionais do corpo político" porque "a igualdade política marca a entrada definitiva no mundo dos indivíduos."3 De fato, a adoção dessa instituição implicava a criação de um universo abstrato de iguais que usufruiam dos mesmos direitos (e obrigações) nas novas repúblicas em formação, como também uma ruptura com os critérios que tinham caracterizado a ordem político-social da colônia. Na prática, a história foi bem mais complexa, mas o certo é que num curto prazo aconteceu a mobilização e a incorporação na vida política de diversos setores da população. As dificuldades para enquadrar essas mudanças dentro de uma ordem estável ficaram evidentes desde cedo, inclusive para aqueles que formaram parte da vanguarda da transformação, mas a busca pelas soluções não desencadeou um retorno às formas e mecanismos do Antigo Regime, ficando restrita à reformulação dos próprios mecanismos da república. Daí as grandes variações entre governos que afirmavam ser, todos eles, fervorosos defensores da soberania popular.

$\mathrm{Na}$ exploração desta dimensão da vida política oitocentista, a pesquisa mais recente escolheu caminhos diversos, ao mesmo tempo em que reconhece um ponto de partida comum de crítica às visões lineares ou progressivas da cidadania e àquelas que apenas a trataram em termos exclusivos de direito de voto. A opção é por uma perspectiva mais ampla que considera diferentes dimensões da vida política e que indaga tanto sobre os princípios e as normas, como sobre as instituições, as práticas, os imaginários e as linguagens em diferentes momentos e lugares. Até hoje os campos mais produtivos nesse sentido estão relacionados com três aspectos da cidadania: a eleitoral, a das armas e a da opinião pública. Os estudos sobre as representações e as práticas ligadas com o sufrágio, as eleições e as formas de representação; as milícias, os exércitos e as revoluções e as instituições da esfera pública, têm gerado novidades importantes que permitem arriscar algumas generalizações e colocar interrogantes para o conjunto do século XIX.

Esse é o ponto de partida mais específico para minhas reflexões. Pretendo encontrar alguns traços e tendências que foram compartilhados em relação com a instituição da cidadania nesses três territórios. No entanto, não questiono a categoria em si mesma, mas a uso do modo em que consigo encontrá-la, para poder aplicá-la como lente de observação das formas de participação política. Os riscos deste exercício são evidentes: na medida em que enfatizo a busca de traços semelhantes em sociedades muito diferentes ao longo de um extenso periodo, as diferenças que sem dúvida existem entre elas em relação aos aspectos por mim tratados ficarão 
ocultas ou minimizadas. Se sou devedora de uma ampla bibliografia, tenho usado ela em função da minha pesquisa, motivo pelo qual muito provavelmente não faça justiça com muitos dos trabalhos que foram indispensáveis para a escrita deste ensaio.

\section{(4)}

\section{0 cidadão eleitor}

4.1. Temos mencionado que o princípio moderno da representação política foi divulgado desde cedo na América Hispânica após a independência, junto com uma concepção renovada de nação. Nem um, nem a outra foram adotados de maneira automática, mesmo que a Constituição de Cádiz tivesse introduzido as noções abstratas de "povo" e de "nação" e definido de modo inovador a figura dos representantes nas colônias americanas e as nações que as sucederam. De fato, circularam e foram utilizadas outras versões de representação.

De qualquer maneira, finalmente venceu o critério de que o governo

Era responsabilidade deles representarem, ao mesmo tempo em que produziam a vontade do povo como entidade abstrata, unitária e soberana (GUERRA, François-Xavier. Modernidad e independencias. Madrid: Mapfre, 1992). Além dos dilemas e paradoxos que implicava dita conceição da representação que, tal como indicara Rosavallon, pressupunha a heterogeneidade social, mas ao mesmo tempo excluía sua expressão política, o certo é que foi divulgada amplamente e desde cedo, e manteve sua vigência pelo menos até o último quarto do século XIX. da nação deveria ficar em mãos daqueles eleitos pelos cidadãos. ${ }^{4}$ Nesse contexto, as eleições ganharam papel central na formação da autoridade legítima. Elas foram o mecanismo formal consagrado para o acesso ao poder governamental, ao mesmo tempo em que foram a forma prescrita de exercício da liberdade política dos cidadãos. A América Hispânica logo se transformou num vasto laboratório de ensaios em torno do sufrágio e das eleições. Por mais que existissem modelos externos, houve uma alta dose de inovação, improvisação e testes, o que the atribuiu perfis próprios à legislação e aos mecanismos eleitorais.

No terreno normativo, a introdução do princípio de representação implicava em definir os dois termos da relação: representantes e representados, o que supunha também, fixar os limites da comunidade política que estava sendo criada. Entre os habitantes de uma nação, quem tinha o direito de eleger e ser eleito? Quem eram os cidadãos? Quem podia ser dirigente? Estas definições implicavam na criação de categorias políticas novas, que não existiam na sociedade colonial. Ou em reformular as velhas.

Em relação ao direito de voto, a região mostra um traço original para a época: em boa parte dela, porém não em toda, esse direito foi estendido para a maior parte da população masculina adulta. Todos os homens livres, independentes, foram incorporados. A exclusão estava associada particularmente com a falta de autonomia e, excetuando os casos pontuais, não foram estabelecidas condições significativas de propriedade ou de capacidade. Assim, em lugar algum os escravos eram donos desse direito que, sim, possuiam, freqüentemente, indígenas e libertos. As condições de idade, sexo e residência eram comuns para todas as áreas, enquanto que em muitas delas (mas não em todas) eram excluídos os homens livres que viviam em relação de dependência (filhos solteiros, serventes e empregados domésticos). Desse modo, na vida política as hierarquias da sociedade colonial foram sendo parcialmente apagadas em função das novas classificações.

Ao longo do século, esses contornos iniciais do direito de voto foram muitas vezes questionados, mas as propostas de limitação poucas vezes se concretizaram em legislação efetiva e o critério mais divulgado de exclusão continuou sendo a falta de autonomia. Somente nas últimas duas décadas aconteceram mudanças significativas nesse terreno. 
Se a base eleitoral estava caracterizada pela sua amplitude, o universo dos elegiveis era inicialmente mais restrito porque para os representantes eram estipuladas condições de propriedade e de capacidade, e quando o sistema de votação era indireto, essas mesmas condições valiam para eleitores de segundo e terceiro grau. Essa normativa dava forma a um universo político de base extensa e estrutura hierarquizada, hierarquia esta que não necessariamente tinha superposição com a correspondente do mundo social; ela respondia mais a um critério aristocrático da vertente republicana: os representantes deviam ser os melhores para encarnar a vontade ou a razão coletiva, e as eleições, o método apropriado para selecionar quem era definido como apto. Mas não existia um sistema previsto para que surgissem as candidaturas, porque se esperava que aparecessem "naturalmente" ou que resultassem da deliberação nos novos corpos políticos intermediários.

4.2. Esses contextos normativos iniciaram o caminho para o funcionamento de mecanismos concretos destinados à produção do fato eleitoral, desde a definição das candidaturas até a concretização do voto, etapas problemáticas para os construtores da nova ordem. No caso dos candidatos, e ainda dentro dos parâmetros estabelecidos pela lei, era colocado o problema do "como". Como selecioná-los? Quem faria essa seleção? Era possível ou desejável essa concorrência? Com relação ao recrutamento e a mobilização dos eleitores, as normas também deixavam um amplo campo aberto para as incertezas e, em conseqüência, a produção do sufrágio não foi tarefa simples. Diferentes regimes ensaiaram formas diferentes de enfrentar essas interrogações, mas a verdade é que ao longo do século e em toda a região foram realizadas eleições regulares e freqüentes e as práticas eleitorais tiveram um papel decisivo na conformação de uma esfera política que tinha relações bastante complexas com a esfera social, mas que de modo algum podia se submeter a ela.

Alguns traços comuns do panorama eleitoral visualizam bem o fantástico desdobramento político decorrente da experiência do sufrágio: em relação à definição das candidaturas, o fato de pressupor uma seleção automática dos melhores em geral, não deu certo e também não funcionou a deliberação racional dos sistemas de representação indireta. Logo mais a concorrência pelo poder desencadeou confrontos entre os grupos que procuravam se impor com candidatos próprios, em disputas muitas vezes permeadas pela violência. A procura de soluções empíricas nesta questão inclinou-se pelo ensaio de variantes diversas na tentativa de evitar a guerra: a negociação entre grupos para elaborar listas comuns; a criação do sufrágio de cima para baixo em sistemas de unanimidade fundados sob "a representação invertida"; a organização de agrupações eleitorais de longa data que começaram a se identificar com os "partidos".

Esta última variante apresentava um problema. 0 termo costumava ser utilizado para a identificação de posições diferentes no debate público, mas em princípio não implicava na permanência ou na cristalização institucional e menos ainda numa associação estrita com a criação e promoção de candidaturas concorrentes. A predominância de uma visão da nação política como unidade, dos eleitos como representantes do interesse coletivo e não de algum interesse em particular, e das eleições como método de seleção dos melhores para encarnar o conjunto, tornava problemática qualquer organização eleitoral associada com "partidos". Mesmo assim, esta asso- 
MANIN, Bernard. Los principios del gobierno representativo. Madrid: Alianza, 1999. ciação começou a acontecer de fato, sendo que a tensão entre os anseios de representar o povo como totalidade e a necessidade de se organizar para ganhar, ficaram contidas na figura do "partido".

Isto nos conduz para o segundo ponto, o das práticas ligadas com o comício eleitoral. Ressalvarei algumas características comuns:

- Apesar da ampla extensão do sufrágio, apenas uma quantidade menor e variável da população habilitada para votar assistia aos comícios. Mas mesmo sendo poucos, os votantes tinham uma ampla origem dentro do espectro social: desde o artesanato urbano até os setores profissionais, os camponeses e as classes laboriosas da cidade e do campo. É claro que analisar os votantes como indivíduos seria enganoso: votar era um ato coletivo e os participantes chegavam no comício organizados em grupos previamente constituídos como forças eleitorais.

- Essa organização era resultado da atividade dos dirigentes porque para eles a chave do sucesso eleitoral era a criação e mobilização das clientelas. Dada a extensão do sufrágio, contavam com uma base potencial muito ampla e a partir dela formavam organizações de estrutura piramidal, verdadeiros seguidores que participavam das lutas eleitorais. Essas "máquinas" estavam alicerçadas por complexos laços que incluiam múltiplas e muito desiguais trocas entre seus integrantes. Esses vínculos eram forjados fundamentalmente na ação política; frequentemente a proeminência de seus dirigentes não era baseada na sua fortuna ou no seu prestígio social prévio, como foi no caso dos "notáveis" definidos por Bernard Manin, mas eram construidos a partir da inserção e da atividade política. ${ }^{5}$ Nos "trabalhos eleitorais" eram definidos e reproduzidos os laços entre caudilhos e suas bases, através de uma dinâmica de relação vertical, direta, que era estabelecida e confirmada na própria ação.

- A atividade eleitoral virou um motor fundamental na vida partidária. De fato não era a única, mas a mais permanente e a que requisitava bases concretas. As agrupações políticas tinham também outro plano de atuação mais geral, executado pelos dirigentes. Através de sua ação parlamentaria, na imprensa e em outros âmbitos da esfera pública, eles apontavam para um público amplo e indiferenciado: o "povo" em geral.

- No entanto, esse povo exercia seu direito de voto apenas de modo parcial. Frequentemente a historiografia associou essa participação minoritária com indiferença política. Porém, muitas das pessoas que não se interessavam em votar, tinham suas simpatias partidárias e eram interessadas pelos resultados eleitorais. Somente que não consideravam necessário ou conveniente ou até recomendável, se imiscuir nesses territórios. A imagem de um povo ansioso por exercer o direito do voto resulta, em muitos casos, anacrônica.

- Os comícios eleitorais foram assim o território de grupos militantes ativos dispostos para o embate eleitoral em todas suas facetas. Frequentemente o sucesso nas urnas não dependia tanto de conseguir votos próprios, mas de impedir os alheios. Nesses casos para os dirigentes era mais importante garantir uma organização fiel e eficaz desses "elementos eleitorais" do que expandir o número de votantes. Porém, isso não excluía a procura de maiores apoios entre o restante da população que, por mais que não participasse na emissão do voto, constituía um público com opinião política que, tal como veremos a seguir, também contava na hora de legitimar a autoridade.

Estes traços foram comuns para diferentes regimes da América Hispânica. Aqueles que pretendiam liderar a vida política cumpriram um papel 
fundamental porque para conseguir a liderança deviam, ao mesmo tempo, se impor sob seus pares e estabelecer mecanismos de ligação com setores maiores da população. Nesse jogo, ficavam em cena recursos, habilidades e destrezas muito diversas, que não estavam reservadas para quem ocupava o cume da pirâmide social. A carreira eleitoral abria assim o caminho do dirigente político para setores maiores do que então era conhecido como "gente decente".

Os regimes eleitorais que compartilhavam os traços mencionados foram eficientes para produzir o sufrágio e a representação, mas não foram suficientes para conseguir sustentar a ordem política. 0 sistema dependia, sobretudo, da força dos caudilhos locais e dos hábitos de mobilização das camadas populares, motivos que o tornavam muito instável e incerto. 0 desacople entre cidadãos potenciais e votantes efetivos, o recorte social destes e a violência recorrente nos comícios foram objeto de crítica permanente e de impugnação. No último terço do século, as críticas foram cada vez mais fortes, na medida em que dentro do setor dirigente foram se afirmando aqueles que procuravam centralizar o poder e consolidar o estado para garantir uma ordem que tinha mostrado ser difícil de conseguir. Nesse contexto, foram introduzidas mudanças nos sistemas eleitorais: em alguns paises o direito de voto foi restrito; em outros, a liberdade e a concorrência eleitorais foram limitadas por outros métodos e, na região toda, o poder central ajustou os controles sobre a vida eleitoral.

Estas mudanças também estão ligadas com as transformações no plano das concepções em vigor sobre a representação e nas linguagens politicas no seio das quais essa noção era articulada. A questão da pluralidade de interesses que uma sociedade abrange ganhou força política, o que fez explodir as visões unanimistas de nação e de representação próprias das décadas centrais do século XIX. Porém, o sistema de governo devia garantir a representação dos diferentes grupos e classes que integravam o todo social, e o partido virou instituição apropriada para representar uma diversidade social que devia encontrar seu contraponto no plano político. A república mudou seu perfil para iniciar uma nova etapa da modernidade hispano-americana.

\section{(5)}

\section{Cidadãos em armas}

Desde os inícios desta experiência republicana, a cidadania ficou estreitamente associada com o direito e o dever de portar armas em defesa da pátria. A instituição da milícia teve, nesse sentido, um papel fundamental. As milícias não eram somente uma força militar: elas representavam "o povo em armas".

A convicção de que a defesa da república tanto dos inimigos esternos quanto dos internos era obrigação dos próprios cidadãos e que responsabilizar um exército profissional por ela abriria as portas da corrupção e da tirania, tem sua raiz nas repúblicas clássicas. No entanto, esse princípio várias vezes foi recusado por aqueles que sustentavam a conveniência e a maior eficiência dos exércitos profissionais. Essa diferença de critérios abriu um espaço para diferentes soluções. Na América Hispânica do século XIX, com a criação de milícias cidadãs foi recuperada uma tradição colonial: a Coroa, que mantinha forças regulares nos seus territórios - os "corpos veteranos" - também tinha fomentado a criação de batalhões integrados 
pelos vizinhos para a defesa local. Essas forças tiveram um papel muito ativo em tempos de guerras que terminaram na independência. Mas foi com a instauração dos novos regimes que a instituição passou a ser considerada um pilar da comunidade política, fundada na soberania popular. Nas primeiras décadas independentes foram estabelecidas milicias urbanas e provinciais e, mais na frente e baseados no mesmo principio, a Guarda Nacional foi criada em vários países. Os exemplos dos Estados Unidos e da França revolucionária inspiraram o desenho das forças milicianas que, nas décadas de 1830 e 1840, foram consideradas um modelo militar mais apropriado para a república do que aquele representado pelos exércitos regulares. Porém, ambas as formas de organização militar coexistiram com freqüência e concorreram conflituosamente até o último terço do século, quando em quase todo lugar as forças profissionais conseguiram se impor.

As milícias eram formadas pelos cidadãos, os mesmos que formavam parte do eleitorado. Em quase todos os locais regiam as mesmas condições para uns e para outros, por mais que o serviço das armas fosse obrigatório e o sufrágio não. Na prática, a organização miliciana teve muitos pontos de contato com a organização que predominava nas máquinas eleitorais. Os milicianos também faziam parte de corpos hierarquicamente ordenados, com uma ampla base e com dirigentes que eram ao mesmo tempo militares e políticos, e cujas ligações eram reforçadas tanto através de relações verticais de subordinação nutridas de cotas variáveis de deferência e paternalismo, quanto de laços horizontais de camaradagem e espírito de grupo.

Se bem a legislação obrigava o amplo recrutamento, as classes acomodadas em geral esquivavam-se do serviço e somente os mais jovens e politicamente ambiciosos participavam, procurando as vagas de mando dos corpos milicianos. Em geral os oficiais provinham dessas classes ou das fileiras dos novos setores intermediários e também era freqüente encontrar artesãos, comerciantes ou capatazes, e gerentes de fazendas e sítios nessas vagas e até entre os milicianos de base. Mas a grande maioria destes últimos provinha das classes populares.

As milicias eram forças de grande enraizamento local e escassa subordinação ao poder central, que conseguiram um papel político fundamental. Não somente houve estreitas conexões entre elas e as forças eleitorais como assim também elas, como forças militares, participaram em quase todos os conflitos armados do período, argumentando uma legitimidade oriunda da sua própria natureza: a de ser a "cidadania em armas". Junto com as forças regulares formaram parte dos conflitos interestatais, na proteção das fronteiras nacionais, mas sobretudo, nos conflitos políticos internos de cada país e na maioria das revoluções, tanto do lado rebelde quanto do oficial.

Em termos normativos, durante boa parte do século XIX, o uso da força era considerado legítimo quando a república corria risco. Perante um governo considerado despótico ou um tirano que abusava do poder, os cidadãos tinham o direito e o dever de se rebelar. As milícias atuaram precisamente no exercício desse direito e no cumprimento desse dever, o que remetia tanto à velha tradição pactista espanhola quanto às novas influências republicanas. Assim, guardas nacionais e cívicas eram mobilizadas pelos caudilhos regionais, governadores de províncias, e comandantes locais nas disputas travadas entre eles mesmos e contra o governo central, em nome da liberdade e contra o despotismo. Nesse contexto, as revoluções não eram concebidas como rupturas, mas como restauração da ordem violen- 
tada pelo tirano da vez. E formaram parte das práticas políticas consideradas legítimas por várias gerações.

No mesmo plano, e já nas últimas décadas do século, em vários paises foram introduzidas mudanças decisivas: o triunfo de grupos que promoviam a centralização política e a consolidação da ordem estatal implicou no fim das milícias, na afirmação do exército profissional e no abandono da concepção republicana fundadora das revoluções.

\section{(6)}

\section{Cidadãos e opinião pública}

A opinião pública foi um dos pilares conceituais sobre o qual foi construida a ordem política pós-revolucionária porque era, junto com a representação, a base fundamental para a legitimação do poder na república. Sejam quais fossem as concepções de opinião pública predominantes em cada momento e local, ela esteve vigente nas origens da instauração dos direitos civis, tais como as liberdades de reunião, de associação e de expressão, de criação e desenvolvimento de instituições e práticas que tiveram função chave na vida política oitocentista. Se os direitos definiram as margens da cidadania civil, as instituições foram seus âmbitos de exercício - o resultado de uma dinâmica complexa na qual operavam tanto forças geradas do alto para baixo pelos governos e os dirigentes que procuravam dar forma e ao mesmo tempo controlar essa instância supostamente autônoma do poder político, quanto iniciativas que nasciam de baixo para cima na própria sociedade.

Nos primeiros tempos republicanos, entre as elites pós-revolucionárias a opinião pública era entendida como a expressão racional da vontade dos cidadãos livres, nascida no seio dos novos espaços de sociabilidade, das associações modernas, e da imprensa periódica, âmbitos apropriados de deliberação racional. Mas se em termos conceituais a opinião estava associada com um público abstrato de indivíduos racionais, na prática virou uma instância disputada na medida em que diferentes grupos e vozes intervinham em nome de públicos concretos. De qualquer maneira, nessas décadas o impulso maior para a forja de uma opinião pública provinha das elites políticas e dos governos e essa foi, sobretudo, uma instância monopolizada pelos grupos minoritários e materializada em instituições tais como a imprensa oficial ou a paraoficial como também algumas associações de elite. Do mesmo modo, esteve marcada pela coexistência de diferentes formas de sociabilidade e de intervenção pública que não respondiam aos critérios incentivados pelas elites ilustradas, mas que tinham efeitos importantes na vida política.

Em meados do século aconteceram mudanças decisivas nessa dimensão da ação cidadã, resultado do processo de formação de uma sociedade civil relativamente autônoma. Seu sintoma mais evidente foi a expansão da atividade associativa nas principais cidades, cuja força impulsora provinha cada vez mais da auto-organização da própria sociedade. Essa atividade convocava setores muito amplos da população e tinha um enorme prestígio porque era considerada, junto com a imprensa independente, expressão da civilidade e escola de cidadania.

Associações e imprensa não somente atuavam no terreno limitado da representação, defesa ou proteção dos interesses e opiniões específicos de suas próprias bases, mas também constituiam tecidos conectivos que percorriam e articulavam a sociedade, vertical e horizontalmente. Além 
disso, criavam espaços de interlocução com o estado e as autoridades, dando lugar à formação de esferas públicas.

Deste modo foi sendo constituído um heterogêneo mundo de instituições e práticas que envolviam pessoas muito diferentes, um mundo que parece ter ficado bastante longe da imagem ideal do "público" cuja vontade era invocada como fundamento de poder. Mesmo assim, e em função desse ideal, boa parte das intervenções era feita em nome do bem comum; os públicos concretos eram apresentados em singular ("o público") pretendendo encarnar a opinião da nação.

A relação deste público ou públicos com o Estado era muito variável, mas as elites políticas não podiam ignorá-los: promoviam a vida associativa, cortejavam a imprensa e respondiam os sinais provenientes da sociedade civil. Também procuravam influir na opinião, para modelá-la, entortá-la e inclusive reprimir seus aspectos mais "subversivos". Nesse contexto, é difícil estabelecer uma distinção clara entre ações e instituições originadas na sociedade civil e aquelas outras gestadas no âmbito político e no Estado. Apesar das diferenças entre umas e outras, elas dividiam parcialmente espaços, práticas, dirigentes e coletividades, e falavam a mesma linguagem política.

No último terço do século foram observadas mudanças importantes neste sentido. A sociedade civil foi mostrando uma autonomia e complexidade cada vez maiores, ao mesmo tempo em que suas instituições fragmentaram as demandas e as vozes, e atuaram cada vez mais em defesa de suas respectivas bases. Os conflitos e tensões sociais procuraram se manifestar na esfera pública: a linguagem dos interesses particulares foi deslocando a retórica cívica da virtude republicana, por mais que ambos continuaram coexistindo durante muito tempo.

\section{(7)}

Até aqui, o percurso pela experiência republicana com foco na cidadania foi uma experiência complexa, múltipla e original na qual, e apesar da diversidade, pode-se reconhecer um padrão comum de trânsito político, caminhos paralelos de experimentação nisso que denominamos modernidade. Para concluir, eu gostaria de pontuar alguns traços comuns perceptiveis nesta história diversa e ao mesmo tempo compartilhada.

A cidadania foi uma instituição chave nas diferentes definições de república e de nação que circularam no século XIX. No plano dos princípios e das representações, ela introduziu o ideal da igualdade fundada sobre os direitos, que teve diferentes versões, mas que enraizou com certa força o imaginário coletivo de várias gerações. Ao mesmo tempo, ocupou um lugar central na vida política prática. Três instâncias foram decisivas nesse sentido: as eleições, as milicias e as instituições da opinião pública. Não foram as únicas, mas as que em todos os períodos caracterizaram as tentativas de constituição de uma ordem política legítima e a criação de espaços concretos de ação política destinados a organizar, conseguir, sustentar e impugnar o poder.

Nessa mesma ordem era dada a incorporação efetiva na vida política de amplos setores da população. A cidadania abria as portas das milicias e das redes eleitorais para a maioria dos homens adultos, enquanto que as liberdades civis habilitavam outros tantos para ser parte ativa na esfera pública. Porém, essa inclusão, em princípio igualitária, aconteceu no contexto de estruturas estratificadas, nas quais eram definidas e nutridas 
as novas hierarquias. 0 povo das milícias e dos comícios era aberto pela lei, mas limitado pela prática e sua intervenção acontecia coletivamente dentro de organizações solidamente verticalizadas que implicavam em subordinação aos dirigentes e em escassa autonomia. No terreno mais fraco das instituições ligadas com a formação da opinião pública, como a imprensa periódica e as associações voluntárias, a situação foi um pouco diferente. Nelas os cidadãos eram mais variados e numerosos e as ligações forjadas entre eles acabavam sendo bem mais igualitárias e autônomas - sobre tudo na segunda metade do século XIX - mas também não ficaram livres de hierarquias e discriminações.

Portanto, e em seu conjunto, a vida política fundada sobre o principio da igualdade gerou espaços de ampla e, ao mesmo tempo, estratificada intervenção nos quais a desigualdade nascia da própria ação política e era nutrida por ela mesma. Essas hierarquias criadas em sedes políticas, dificilmente refletiam as correspondentes do mundo social, por mais que ficassem parcialmente superpostas a elas, porque reconheciam outros canais de gestação e de reprodução. Nesse contexto, a tensão - às vezes visível - entre a igualdade de direitos e a desigualdade de fato gerou poucos questionamentos à legitimidade do sistema. Tampouco o fez o predomínio de formas coletivas de participação política que pouco facilitavam a intervenção individual autônoma. Somente em finais do século aquela tensão e estas formas começariam a ser tematizadas como problema no contexto de maiores transformações das relações entre política e sociedade, anunciadoras de uma nova época.

Estes últimos pontos colocam interrogações sobre a questão da igualdade de direitos, as desigualdades políticas e sociais e as formas de inclusão na vida política, tanto por cima como por baixo. Fica em aberto o problema das diferentes formas de construção de hierarquias na vida política, das relações verticais e horizontais no seio de suas estruturas, da permeabilidade e dinamismo para as mudanças, enfim, das diversas formas de criação, funcionamento e mutação dos mecanismos, formais e informais, de intervenção cidadã. Também, no terreno das representações surge a questão em volta daquelas que deixavam clara a intervenção, ou a falta de intervenção, dos diferentes setores da população em diversas instâncias da vida política, e do lugar simbólico ocupado pela cidadania nesse sentido. Voltamos à pergunta recorrente sobre quem participava, por que participava e com quais resultados. E sobre as exclusões.

$\mathrm{Na}$ outra ponta do novelo, o tema dos dirigentes é inevitável e tem recebido relativamente pouca atenção nos últimos tempos. No contexto de um formidável processo de redefinição, mudanças e ampliações, esses dirigentes foram atores centrais do drama republicano. Como nasceram e se diversificaram, quais foram as relações estabelecidas entre eles e com o restante da população, qual era a ligação com as classes proprietárias nos seus diferentes niveis e como era a relação com o estado: são perguntas que ultrapassam o tema específico da cidadania, mas que estão relacionadas com ele de um modo inegável.

Por último, fica a questão dos resultados. Apesar da vontade e da energia dispensadas para construir uma nova ordem, durante longas décadas os resultados foram instáveis e efêmeros, fato que fez com que os contemporâneos questionassem várias vezes as bases mesmas nas quais era procurada a consolidação do poder e praticado o ensaio de possíveis alternativas. Somente no último quartel do século XIX foi alcançada a 
consolidação parcial dessa forma relativamente estável que denominamos estado-nação, no jargão contemporâneo. Naquela época, as nações latinoamericanas experimentavam transformações importantes: suas economias cresciam sustentavelmente em estreita relação com o capitalismo e com o mercado internacional, e suas sociedades iam sendo cada vez mais diversificadas e complexas. Novas ideologias propunham outras formas de entender a política e sua relação com o social. As propostas e práticas políticas próprias do legado republicano foram cada vez mais alvo de críticas, tanto "pela direita" quanto "pela esquerda". A linguagem das classes rapidamente substituiu a retórica da unanimidade própria das décadas anteriores e foram surgindo novas formas de fazer política. Para uma parte da elite em ascensão social, a ordem desejada somente poderia ser alcançada com o fortalecimento do poder central e a consolidação do estado. Apesar de que não em todos os casos essas metas fossem conseguidas, a região inteira ficou norteada decididamente nessa direção. Uma nova modernidade estava sendo moldada. Suas próprias contradições ficariam evidentes rapidamente quando, a princípios do século XX, a questão da democracia começasse a nascer com dificuldades e conflituosamente.

Em resumo: o século XIX foi o século da república. Foi inaugurado num gesto radical que procurava instaurar a igualdade politica entre os integrantes das novas nações em formação, rompendo nesse plano com suas ramificações em estruturas comunitárias e estratificações prévias. Esse gesto abriu caminhos para a mobilização e o reagrupamento maciço de pessoas que passaram a ocupar um lugar político diferente daquele que tiveram previamente. Foram criadas novas formas e hierarquias politicas definidas com certa autonomia em relação com o social e que se afastavam decididamente das tradições do Antigo Regime. Estas novas desigualdades não eram compatíveis com a ordem republicana; pelo contrário, nasciam de sua própria dinâmica. Portanto, é anacrônico pensar o século XIX em termos de democracia e avaliar sua vida política em relação com ideais que não predominaram na América Latina e que somente mais tarde enraizariam nela. Com efeito, o século XX começou com a reafirmação do mesmo princípio de igualdade instaurado durante as décadas da república, mas numa vertente nova: fazer com que essa igualdade de direito fosse também, no terreno político, uma igualdade de fato, com a introdução de formas democráticas de organização e de governo. Somente então ganhou vigor o horizonte da democracia política.

Tradução: Marisa Montrucchio 
AGUILAR RIVERA, José Antonio. En pos de la quimera. Reflexiones sobre el experimento constitucional atlántico. México, D.F.: Fondo de Cultura Económica, 2000

AGUILAR RIVERA, José Antonio; ROJAS, Rafael (coord.). El republicanismo en Hispanoamérica. Ensayos de historia intelectual y politica. México D.F.: Fondo de Cultura Económica, 2002.

AGULHON, Maurice; BRAVO LIRA, Bernardino et al. Formas de sociabilidad en Chile, 1840-1940. Santiago de Chile: Editora Vivaria, 1992.

ALJOVÍN, Cristóbal; LÓPEZ, Sinesio (eds). Historia de las elecciones en el Perú. Estudios sobre el gobierno representativo. Lima: Instituto de Estudios Peruanos, 2005

ALONSO, Paula. Between Revolution and the Ballot Box. The Origins of the Argentine Radical Party. Cambridge: Cambridge University Press, 2000.

ALONSO, Paula (comp.). Construcciones impresas. Panfletos, diarios y revistas en la formación de los estados nacionales en América Latina, 18201920. Buenos Aires: Fondo de Cultura Económica, 2003.

ANNINO, Antonio; ROMANELLI, Raffaele. Premesa. Quaderni Storici, nuova serie, 69, 1988.

ANNINO, Antonio (coord). Historia de las elecciones en lberoamérica, siglo XIX. De la formación del espacio político nacional. Buenos Aires: Fondo de Cultura Económica, 1995.

ARROM, Silvia M.; ORTOLL, Servando (eds.). Riots in the Cities. Popular Politics and the Urban Poor in Latin America, 1765-1810. Wilmington: SR Books, 1996.

BASADRE, Jorge. Elecciones y centralismo en el Perú. Lima: Centro de Investigación de la Universidad del Pacífico, 1980.

BEATTIE, Peter M. The Tribute of Blood. Army, Honor, Race and Nation in Brazil, 1864-1945. Durham and London: Duke University Press, 2001.

BELLINGERI, Marcos. Dal voto alle baionette: esperienze elettorali nello Yucatan costituzionale ed indipendente". Quaderni Storici, nuova serie, 69, 1988.

BOTANA, Natalio. El orden conservador. Buenos Aires: Sudamericana, 1977.

BOTANA, Natalio. La tradición republicana. Buenos Aires: Sudamericana, 1984.

BRADING, David. The First America: The Spanish Monarchy, Creole Patriots and the Liberal State, 1492-1867. Cambridge: Cambridge University Press, 1991.

BUVE, Raymond. Between Ballots and Bullets: Long-term Trends in Nineteenth-Century Mexican Political Culture. In: PANSTERS, Wil G.(ed). Citizens of the Pyramid. Essays on Mexican Political Culture. Ámsterdam: Thela Publishers.1997

CANSANELLO, Oreste Carlos. De súbditos a ciudadanos. Ensayo sobre las libertades en los orígenes republicanos. Buenos Aires: Imago Mundi, 2003. 
CHAMBERS, Sarah C. From Subjects to Citizens. Honor, Gender, and Politics in Arequipa, Peru, 1780-1854. University Park (Pennsylvania): The Pennsylvania State University Press, 1999.

CHAVES DE MELLO, Maria Tereza. A República Consentida. Cultura democrática e científica do final do Império. Rio de Janeiro: Editora FGV, 2007.

CHIARAMONTE, José Carlos. Ciudades, provincias, estados: orígenes de la Nación Argentina (1800-1846). Buenos Aires: Ariel, 1997.

CHIARAMONTI, Gabriella. Riforma Elettorale e Centralismo Notabilare a Trujillo (Peru) tra Otto e Novecento. Quaderni Storici, nuova serie, 69, 1988.

CHIARAMONTI, Gabriella. Ciudadanía y representación en el Perú (18061860). Los itinerarios de la soberanía. Lima: Fondo Editorial UNMSM, SEPS e ONPE, 2005.

DEAS, Malcom. Algunas notas sobre la historia del caciquismo en Colombia. Revista de Occidente, 127, 1993.

DE CARVALHO, José Murilo. Os bestializados. O Rio de Janeiro e a República que não foi. São Paulo: Companhia das Letras, 1987.

DE CARVALHO, José Murilo. A formação das almas. O imaginário da república no Brasil. São Paulo: Companhia das Letras, 1990.

DE CARVALHO, José Murilo. Desenvolvimiento de la ciudadanía en Brasil. México: Fideicomiso de Historia de las Américas de El Colegio de México e Fondo de Cultura Económica, 1995.

DEL AGUILA, Alicia. Callejones y mansiones: espacios de opinión pública y redes sociales en la Lima del 900. Lima: Pontificia Universidad Católica del Perú, 1997.

DI MEGLIO, Gabriel. iViva el bajo pueblo! La plebe urbana de Buenos Aires y la politica entre la Revolución de Mayo y el rosismo. Buenos Aires: Prometeo, 2006.

DUNKERLEY, James (ed.). Studies in the Formation of the Nation State in Latin America. London: ILAS, 2002.

EARLE, Rebecca (ed.). Rumours of Wars: Civil Conflict in Nineteenth-Century Latin America. London: ILAS, 2000.

ESCALANTE, Fernando. Ciudadanos imaginarios. México: El Colegio de México, 1992.

FORMENT, Carlos. Democracy in Latin America, 1760-1900. Vol. I: Civic Selfhood and Public Life in Mexico and Peru. Chicago: University of Chicago Press, 2003.

GAZMURI, Cristián. EI "48" chileno. Igualitarios, reformistas, radicales, masones y bomberos. Santiago de Chile: Editora Universitaria, 1992.

GONZÁLEZ BERNALDO, Pilar. Civilité et politique aux origines de la nation Argentine. Les sociabilités a Buenos Aires, 1829-1862, Paris, 1999.

GRAHAM, Richard. Patronage and Politics in Nineteenth-Century Brazil. Stanford: Stanford University Press, 1990.

GUARDINO, Peter. The Time of Liberty. Popular Political Culture in Oaxaca, 1750-1850. Durham y Londres: Duke University Press, 2005. 
GUEDEA, Virginia. Las primeras elecciones populares en la ciudad de México, 1812-1813. Estudios Mexicanos, 7, 1, 1991.

GUERRA, François-Xavier; LEMPÉRIERE, Annick; et al. Los espacios públicos en Iberoamérica. Ambiguedades y problemas. Siglos XVIII-XIX. México: Fondo de Cultura Económica, 1998.

GUERRA, François-Xavier. Modernidad e independencias. Madrid: Mapfre, 1992.

GUERRA, François-Xavier. Las metamorfosis de la representación en el siglo XIX. In: COUFFIGNAL, Georges (comp.). Democracias posibles. El desafio latinoamericano. Buenos Aires: Fondo de Cultura Económica, 1993.

GUTIÉRREZ, Francisco. Curso y discurso del movimiento plebeyo, 1849/1854. Bogotá: El Ancora Editores, 1995.

HALPERIN DONGHI, Tulio. Revolución y guerra. Formación de una elite dirigente en la Argentina criolla. Buenos Aires: Siglo XXI, 1972.

HALPERIN DONGHI, Tulio. Proyecto y construcción de una nación. (Argentina 1846-1880). Caracas: Biblioteca de Ayacucho, 1980.

HALPERIN DONGHI, Tulio. Reforma y disolución de los imperios ibéricos, 1750-1850. Madrid: Alianza, 1985.

HERNÁNDEZ CHÁVEZ, Alicia. Origen y ocaso del ejército porfiriano. Historia Mexicana, 153, 1, 1989.

HERNÁNDEZ-CHÁVEZ, Alicia. La tradición republicana del buen gobierno. México: Fideicomiso de Historia de las Américas de El Colegio de México e Fondo de Cultura, Económica, 1993.

IRUROZQUI, Marta. Ebrios, vagos y analfabetos. El sufragio restringido en Bolivia, 1826-1952. Revista de Indias. LVI, 208, 1996.

IRUROZQUI, Marta. Las paradojas de la tributación. Ciudadanía y política estatal indígena en Bolivia, 1825-1900. Revista de Indias, LIX, 217, 1999.

IRUROZQUI, Marta. "A bala, piedra y palo" La construcción de la ciudadanía politica en Bolivia, 1826-1952. Sevilla: Diputación de Sevilla, 2000.

IRUROZQUI, Marta. La ciudadanía en debate en América Latina. Discusiones historiográficas y una propuesta teórica sobre el valor público de la infracción electoral. Lima: Instituto de Estudios Peruanos (Documento de Trabajo No. 139), 2004.

KÖNIG, Hans-Joachim. Auf dem Wege zur Nation: Nationalismus im Prozess der Staats- und Nationsbildung Neu-Granadas 1750-1856. Stuttgart, 1988.

LOMNITZ, Claudio. Ritual, Rumor and Corruption in the Constitution of Polity in Modern Mexico. Journal of Latin American Anthropology, 1,1, 1995.

LÓPEZ JIMÉNEZ, Sinesio. Ciudadanos reales e imaginarios. Concepciones, desarrollo y mapas de la ciudadanía en el Perú. Lima: Instituto Diálogo y Propuestas, 1997.

MALAMUD, Carlos (comp.). Partidos políticos y elecciones en América Latina y la Península Ibérica, 1830-1930. Madrid: Instituto Universitario Ortega y Gasset, 1995.

MALAMUD, Carlos; DARDÉ, Carlos (eds.). Violencia y legitimidad. Politica y revoluciones en España y América Latina, 1840-1910. Santander: Universidad de Cantabria, 2004. 
MALLON, Florencia. Peasant and Nation. The Making of Postcolonial Mexico and Peru. Berkeley and Los Angeles, 1995.

McEVOY, Carmen. Estampillas y votos: el rol del correo político en la campaña electoral decimonónica. Histórica, XVIII, 1, 1994.

McEVOY, Carmen. La utopía republicana. Ideales y realidades en la formación de la cultura política peruana (1871-1919). Lima: Pontificia Universidad Católica del Perú, 1997.

McFARLANE, Anthony; POSADA CARBÓ, Eduardo (eds.). Independence and Revolution in Spanish America: Perspectives and Problems. London: ILAS, 1999.

MUECKE, Ulrich. Political Culture in Nineteenth-Century Peru. The Rise of the Partido Civil. Pittsburgh: University of Pittsburgh Press, 2004.

MYERS, Jorge. Orden y virtud. El discurso republicano en el régimen rosista. Bernal: Universidad Nacional de Quilmes, 1995.

NEGRETTO, Gabriel; AGUILAR RIVERA, José Antonio. Rethinking the Legacy of the Liberal State in Latin America: The Cases of Argentina (1853-1916) and Mexico (1857-1910). Journal of Latin American Studies, 32, 2, 2000.

PALTI, Elias. La invención de una legitimidad. Razón y retórica en el pensamiento mexicano del siglo XIX (Un estudio en las formas del discurso político). México: FCE, 2005.

PALTI, Elias. El tiempo de la política. El siglo XIX reconsiderado. Buenos Aires: Siglo XXI, 2007.

PAMPLONA, Marco. Riots, Republicanism and Citizenship. New York City and Rio de Janeiro City During the Consolidation of the Republican Order. New York and London: Garland Publishing, Inc, 1996.

PELOSO, Vincent. Liberals, Electoral Reform, and the Popular Vote in Mid-nineteenth century Peru. In: PELOSO, Vincent Peloso; TENEMBAUM, Barbara (eds.). Liberals, Politics, and Power: State Formation in Nineteenth. Century Latin America. Athens: 1996.

PERALTA RUIZ, Víctor. Elecciones, constitucionalismo y revolución en el Cusco, 1809-1815. Revista de Indias, LVI, 206, 1996.

POSADA CARBÓ, Eduardo (ed.). Elections Before Democracy. The History of Elections in Europe and Latin America. Houndmills and London: MacMillan Press, 1996.

POSADA CARBÓ, Eduardo. Electoral Juggling: A Comparative History of the Corruption of Suffrage in Latin America, 1830-1930. Journal of Latin American Studies, 32, 3, 2000.

QUIJADA, Mónica. La ciudadanización del 'indio bárbaro'. Políticas oficiales y oficiosas hacia la población indígena de la pampa y la Patagonia, 1870-1920. Revista de Indias, LIX, 217, 1999.

ROMERO, Luis-Alberto. ¿Qué hacer con los pobres? Elite y sectores populares en Santiago de Chile, 1840-1895. Buenos Aires : Sudamericana, 1997.

SABATO, Hilda. Citizenship, Political Participation and the Formation of the Public Sphere in Buenos Aires, 1850s-1880s" Past and Present, 136, 1992. 
SABATO, Hilda. La politica en las calles. Entre el voto y la movilización. Buenos Aires, 1862-1880. Buenos Aires: Sudamericana, 1998. (2ª edição: Bernal: Universidad Nacional de Quilmes, 2004).

SABATO, Hilda (coord.) Ciudadanía política y formación de las naciones. Perspectivas históricas de América Latina. México: Fideicomiso de Historia de las Américas de El Colegio de México y Fondo de Cultura Económica, 1999.

SABATO, Hilda. On Political Citizenship in Nineteenth-Century Latin America. The American Historical Review, 106:4, October 2001.

SABATO, Hilda. El ciudadano en armas: violencia política en Buenos Aires, 1852-1890. In: RIEKENBERG, Michael; RINKE, Stefan; SCHMIDT, Peer (eds.). Kultur-Diskurs: Kontinuität und Wandel der Diskussion um Indentitäten in Lateinamerika im 19. und 20. Jahrhundert. Stuttgart: Heinz, 2001.

SABATO, Hilda. La reacción de América: la construcción de las repúblicas en el siglo XIX. In: CHARTIER, Roger; FEROS, Antonio (coord). Europa, América y el mundo: tiempos históricos. Madrid: Marcial Pons, 2006.

SABATO, Hilda, 2008. Buenos Aires en armas. La revolución de 1880. Buenos Aires: Siglo XXI, 2008.

SABATO, Hilda; LETTIERI, Alberto (coord.). La vida política en la Argentina del siglo XIX. Armas, votos y voces. Buenos Aires: Fondo de Cultura Económica, 2003.

SAFFORD, Frank. Politics, Ideology and Society. In: BETHELL, Leslie (ed.). Spanish America after Independence c. 1820-c.1870. Londres: Cambridge University Press, 1987.

SANDERS, James E. Contentious Republicans. Popular Politics, Race, and Class in Nineteenth-Century Colombia. Durham and London: Duke University Press, 2004.

TERNAVASIO, Marcela. La revolución del voto. Politica y elecciones en Buenos Aires, 1810-1852. Buenos Aires: Siglo XXI, 2002.

THIBAUD, Clément. Républiques en armes. Les armées de Boliver dans les guerres d'indépendence du Venezuela et de la Colombie. Rennes: Presses Universitaires de Rennes, 2006.

THOMSON, Guy. Bulwarks of Patriotic Liberalism: The National Guard, Philharmonic Corps and Patriotic Juntas in Mexico, 1847-88. Journal of Latin American Studies, 22, 1, 1990.

VALENZUELA, J. Samuel. Democratización vía reforma: la expansión del sufragio en Chile. Buenos Aires: Ediciones del IDES, 1985.

WALKER, Charles F. Smoldering Ashes. Cuzco and the Creation of Republican Peru, 1780-1840, Durham and London: Duke University Press, 1999. 